\title{
Examining Maqasid Sharia Attainment: Case of Financing Products of Bank Muamalat Indonesia
}

\author{
Loni Hendri \\ Bersama Institute, Indonesia
}

Article History

Received: December, $2^{\text {nd }} 2021$ Revised: December, $22^{\text {nd }} 2021$ Accepted: December, $22^{\text {nd }} 2022$

\begin{abstract}
Corresponding author:

E-mail:

lonihendri.ge@gmail. com

The objective of the Islamic Bank is still profit-oriented while the Islamic economy, as the mother of the Islamic Bank, has the orientation to obtain the maqasid sharia that agreed as social well-being, which can not always be obtained by profit alone. The first pure sharia Islamic Bank in Indonesia is Bank Muamalat. As the first bank purely shariah, Bank Muamalat commit to promoting services that not only comply with sharia but are also competitive and accessible for entire citizen. Based on this background, this research aimed to evaluate financing products of Bank Muamalat by using the framework of maqasid limited to aspect of justice. This research was descriptive-qualitative using secondary data such as financial statements, types of Bank Muamalat financing products acquired from the Bank Muamalat site and brochure. Results of this research showed that financing products of Bank Muamalat could be considered as the attainment of maqasid sharia because those products are dominantly provided in the equity-based contract. But, the conditions determined for the equity-based contract in Bank Muamalat's financing products make them considered as not promoting maqasid sharia.
\end{abstract}

Keywords: Financing Products. Justice, Maqasid Sharia, Bank Muamalat, Islamic Economy

\section{Introduction}

\subsection{Background}

Based on its operational scope, Islamic Banking in Indonesia extend to every small spot region. In December 2020, Islamic Banking had reached 33 provinces and abroad with total assets of about 583.948 trillion rupiah and 2.426 offices. These services are also supported by 2.982 ATMs and 55.538 employees (OJK, 2020).

How to cite:

Hendri, L. (2021). Examining Maqasid Sharia Attainment: Case of Financing Products of Bank Muamalat Indonesia. Journal of Islamic Economic and Business Research, 1(2), 216-230. https://doi.org/10.18196/jiebr.v1i2.13 
Islamic Banking, globally and nationally, is the prospective industry for investors, businessmen, and society. However, that prospect is only noticed based on its growth in assets, increasing in units, and based on its performances. It rarely happens that Islamic Bank is seen based on its objectives that not only aims for profit but also function socially. This statement is based on the fact that the parameter of Islamic Banking is like a Conventional one, such as in financial performance, which consists of Return on Asset, Return on Equity, Financing to Deposit Ratio, etc.

Perhaps it happens because it has come to fruition that the objective of the Islamic Bank is just about riba-free. It means that Islamic Bank is not given a clear objective, so that the success of the Islamic Bank is just seen from the aspects that only could be measured by conventional parameters. Based on this problem, the exact and clear objective of the Islamic Bank is necessary for that someone could make an exact model of performance measurement for Islamic Bank (Mohammad, Razak, \& Taib, n.y.)

Islamic Bank is a part of the Islamic economy with an equal objective with the Islamic economy itself. Accordingly, the Islamic economy becomes the guidance of the Islamic Bank objective so that the objective of the Islamic Bank has to represent the objective of the Islamic economy. In fact, it is shown that the objective of Islamic Bank is still profit-oriented while the Islamic economy, as the mother of Islamic Bank, has the orientation to obtain the maqasid sharia that agreed as social well-being, which cannot always be obtained by profit alone (Ahmed, 2011) (Mohammad \& Shahwan, 2013)

The well-being of the economy can be realized by practicing economy using legal principles, even distribution and social bases, fair prosperity, no oppression, and balance and simplicity (Indonesia, 2012). That well-being dimension of the economy could be seen in a smaller aspect of the economy of banking. As a part of the Islamic economic system that has social orientation, Islamic Banking could realize one of the maqasid sharia that creates growth and justice in the economy. Realization of the maqasid sharia has to be done not only in the operational aspect (performance) but also in the Islamic Bank product itself (Rosly, 2010). The justice in a product could be obtained by giving the equal right and opportunities to every person to gain continuous economic growth regardless of reins, color, gender or social status (rich and poor) (Yusof, Ogie, \& Kamal, February 2010).

Furthermore, Islamic Banking performance is always evaluated by a conventional parameter that focuses on profit and assets aspects. As the Islamic institution that has not only the orientation of profit but also social orientation, Islamic Bank has to be evaluated in regard to its social responsibilities in the Islamic framework (Mohammad, Razak, \& Taib, n.y.).

The first pure sharia Islamic Bank in Indonesia is Bank Muamalat. Basically, there is no difference in the type of product between Bank Muamalat and Conventional Bank that includes funding products, financing and services. As the first pure sharia bank, it is committed to promoting services that not only comply with sharia but are also competitive and accessible for entire citizens. From 2007 to 2014, Bank Muamalat got six awards as the best Islamic Bank in Indonesia for its product innovation and financial performance (Meryana, 2013; Suharso, 2014). As for 2020, Bank Muamalat got at least seven awards, 
such as Satisfaction Loyalty Engagement Index 2020 for Sharia Bank, 2020 Sharia Commercial Bank Satisfaction Index, Best Customer Experience, Millenial Popular Digital Brand and others (Muamalat, 2020).

\subsection{Objective}

As explained above, one of the maqasid sharia purposes is to obtain economic growth and justice. Islamic Bank could realize the objective through its financing product and its performance. In this regard, the financing product of Bank Muamalat and its social performance were reviewed from maqasid sharia perspective.

This study was conducted for products of Bank Muamalat Indonesia, and it was limited to its financing products. Based on this background and problem limitation, the problem of this study is how financing products of Bank Muamalat was based on maqasid sharia perspective?

\section{Literature Review}

\subsection{Theoretical Background}

Maqasid sharia is a term that consists of two words, Maqasid and Sharia. Maqasid is originated from qasdu, which means straighten the path, fair, moderate, and aim toward something (Auda, 2007). Also, maqasid is a plural word of Arabic maqsud which means objective, principle, purpose, goal, end, or telos in Greek, finalite in France and Zweck in Germany. Auda defined maqasid as a group of divine intents and moral concepts of the Islamic law that are based on justice, free will, holiness, human dignity, facilitation and social cooperation (Auda, 2008).

As for sharia, it is an Arabic term that means a way humans went through or a line that has to be passed. In terminology, sharia is rules and laws that Allah has commanded humans to obey and as the way to connect them with Allah (Karim, 2013).

Maqasid is objective and such, while sharia is rules and laws. Therefore, maqasid sharia is the objectives, intents, ends, or goals behind the Islamic rulings. In other term, maqasid sharia is an alternative expression to people's interests (mashalih) (Auda, 2008; al Mubarak \& Osmani, 2010)

Meanwhile, al-Shatibi defined maqasid sharia as the obligation to obey the sharia by protecting its objectives, including dharuriyat, hajiyyat, and tahsiniyyat (As-Shatibi, 2006). Wahbah al-Zuhayli stated that maqasid sharia means every goal or objective and secret or wisdom exist in each law Allah created for the human to realize human welfare. This welfare could be divided into three broad categories of priority, including essential (dharuriyat), supporting (hajiyyat), and embellishments (tahsiniyyat), its relation to society and person, including general and specific welfare, and the need for it including qat'iyah, zhanniyah, hammiyah (Al-Zuhayli, 1986). Another Islamic scholar, M. Said Ramadhan al-Buti, stated that the objective of Islamic law is to protect five important elements of human life, i.e., religion, life, intellect, wealth, and posterity. These five elements are called mashlahah, which represents a condition that everyone could reach the enjoyment of life and let go of any kind of trouble in their life (Al-Buti, 2005). Meanwhile, Abu Zahrah refined the 
objectives of Islamic law into a specific objective that includes three broad areas of individual education, justice establishment, and welfare promotion, including protection of five elements of human life (religion, life, intellect, wealth, and posterity (Abu Zahrah, 1958).

Maqasid sharia is the goal of the sharia to cover every aspect of human life related to personal, social, economic, political and intellectual. It has to cover all forms of welfare, social justice and make an individual's behavior better off by alleviating hardship and eliminating prejudice.

Islamic economic system has a social orientation that manifests in the economy by enabling justice and growth (Ahmed, 2011). Islamic Bank, as a part of this economic system, has to promote that social orientation. Its social orientation has to be fulfilled both in the products and activities of the bank. For Ahmed, this social orientation could be obtained by Islamic Bank through its market segments and its needs. The market segments mean serving financial needs generally, small or micro-enterprise and also serving poor and middle class. While the need or purpose served means the product has to suit the financial needs of the target population that can be classified into three-level, namely survival, security and growth (Ahmed, 2011).

Another economist suggests that the social orientation of the Islamic Bank could be obtained through its products by emphasizing the legality of products. This legality is not only including the validity of a contract but also ensuring the benefit of each contract to each party (Rosly, 2010).

More specific justice aspect in Islamic Bank products examination was suggested by Yusof et.al. They argued that justice in Islamic Bank through its products could be examined by evaluating the equality of opportunity given by the bank to everyone to access the financial need. This justice means to ensure that everyone gets what they deserve by avoiding discrimination in terms of race, color, sex and status (Yusof, Ogie, \& Kamal, February 2010).

In this context, Islamic Bank financing products are classified into two broad groups of equity-based financing and debt-based financing. There is no problem with equity-based financing because everyone could reach this type of financing. However, the problem arises with debt-based financing because this kind of financing has no equality in opportunity that separates between the poor and the rich. In this kind of financing, the poor have no access to the fund because they have no collateral for it, while the rich can borrow as many as they wish (Yusof, Ogie, \& Kamal, February 2010).

Justice in the economy would be achieved by equal distribution of income and wealth, the equal opportunity given to various skills, and also equal opportunity to access capital (Rawls, 2005). Based on those theories on justice in Islamic Bank, this research will try to use the debt and equity-based financing classification to separate Muamalat financing products in relation to justice attainment in Islamic Banking.

\subsection{Previous Studies}

Some research has been done on maqasid sharia, performance and development of Islamic Bank and its objective related to maqasid sharia. Among those researches is research that 
used specific content analysis to explain the objective of Islamic Bank that should be in line with the objective of the Islamic economy. This research concluded that Islamic Bank was more profit-oriented than the social one (Mohammad \& Shahwan, 2013).

Another research tried to evaluate Islamic Bank performance based on maqasid sharia framework. This research applied the Maqasid Index approach for the measurement of Islamic Banking industry performance by comparing industries in Indonesia and Jordania. The research showed that the Maqasid Index of Islamic Banking in Indonesia which is represented by BSM and BMI was better than Islamic Banking in Jordania, which is represented by IIABJ and JIB (Antonio, D., \& Taufiq, 2012).

Islamic finance has a distinctive role in society, so this institution has to be conducted based on the highest objective of Islamic law (maqasid sharia). Islamic finance is not solely about riba-free and lawful technically in product offering, but a holy system that aims for giving contribution in fulfilling the objective of economic-social and create justice in the society (Dusuki \& Bouheraoua, 2011).

The exact realization of maqasid sharia in Islamic banking and finance faced many challenges such as well understanding of maqasid sharia in the Islamic economy, application methods of maqasid sharia in Islamic banking and financial institution, the potential of conflict between macro maqasid and micro maqasid and the misapplication possibilities of maqasid sharia to legalize any financial contract that at the basic is unlawful in sharia. These challenges can be overcome by that Islamic banking and financial institution ensure that all of their transactions are in line with shariah, not only its form and its legal technique but also its economic substantive. Another aspect is that the institutions have to avoid all kinds of controversial contracts that perhaps will block the growth and development of the banking and financial industry (Abozaid \& Dusuki, 2007).

Hosen and Nahrawi (2012) discussed the cause and background of the fatwa difference between Indonesia and Malaysia on Islamic Bank products. This research was library research and supported by interviews. Its result showed that tawarruq, bai' al innah and bai' al dayn mechanism was not considered as Islamic Bank product in Indonesia due to several physical defects in its contract. As for Malaysia, these kinds of contracts are permitted by basic that, legally, a sale is lawful (Hosen \& Nahrawi, 2012).

Shariah Supervisory Board for Islamic Banks in Malaysia used incoherent legal methods in permitting Islamic Bank products. This is shown on the stern act that only focuses on technic legal on the one hand, and on another hand, it is too flexible about using doctrine in permitting Islamic Bank products. This incoherent act can be handed by using exact unregulated-maslahah doctrine to support Shariah Supervisory Board in exact ijtihad about issues in Islamic banking and finance (Shaharuddin, 2010).

Analysis of maslahah on a project must come first before its commercial analysis and its national profitability because maslahah analysis can be basic for detail step for some priority in project rivalry and many rational choices according to shariah. Furthermore, the concept of maslahah could ensure project coherence with maqasid sharia and the Islamic system completely (Jalil, 2006). 
Accordingly, this research focused on maqasid sharia of Islamic Bank products and its social performance in Indonesia. The chosen bank was Bank Muamalat Indonesia as the first pure sharia bank in Indonesia. The product discussed in this research was financing products of Bank Muamalat that were correlated directly with maqasid sharia attainment. This research was different compared to other research in the economic approach. While many of the former research only discussed the application of maqasid sharia in Islamic Bank performance, this research tried to understand maqasid sharia in financing products of Islamic banking.

\subsection{Conceptual Framework}

Islam is a word that has been known and understood as merely a religion. Sometimes, people forget that Islam is not merely a term or a symbol of a religion. Islam is a comprehensive system including human life in all aspects. Some of these aspects are economic development and the banking industry as the driving force of the economy. Consequently, Islam is not merely a religion and not exclusively related to ritual (Antonio M. S., 2001).

Shariah, as a part of Islam, is a rule and law that Allah determines, and humans are obliged to do it and abided by it as a medium of human relation with Allah and relation among their peers. Since sharia is part of Islam, Islamic law has to be comprehensive and universal. Sharia has to include all of the life aspects (ritual and social) and can be applied anytime and anywhere (it is not only valid for the past and for Muslim only but also valid for the time being and future and include all kind of human regardless their religion) (Karim, 2013). There is no shariah without objectives and goals. Sharia is aimed at human well-being. This objective is then known as maqasid sharia, and human well-being is known as maslahah (Bakri, 1996).

Based on the understanding of Islam, shariah and maqasid sharia, the Islamic economy could be understood as a way or method that trained in Islam related to the economic business of human beings. The objective of the economy in conventional understanding is to fulfill human needs and will. As for Islam, the objective of the economy is to fulfill human needs and will use the right method and not use the wrong one to obtain the maslahah (Indonesia, 2012).

Islamic banking or Shariah banking is a part of the Islamic economy. As part of the Islamic economy, Islamic banking should own the equal objective as the Islamic economy to obtain the maslahah (Mohammad \& Shahwan, 2013). The maslahah that would be obtained is not an individual one (profit and benefit for the bank) but the maslahah for the society (Indonesia, 2012).

Islamic Bank product is a part that can't be separated from Islamic Bank as a driving force of the economy. Based on it, Islamic banking should be part of the process in obtaining maslahah (maqasid sharia) with the legality of its product as the indicator (lawful, riba-free, gharar-free and the kind). Another indicator is the principle of even distribution and society basis (all of the society members, poor, middle and rich have the right to use bank products) (Yusof, Ogie, \& Kamal, February 2010) and unmolested each other (bank and customer both 
get the benefit and carry the lost) (Bedoui \& Mansour, 2013). Equal opportunity to access capital for each person in society is what justice in an economy is. Islamic Bank, as the intermediary institution, is both capital user and provider in society. It provides capital through its financing products. Justice in Islamic Bank means how the bank provides capital for everyone equally through its financing products.

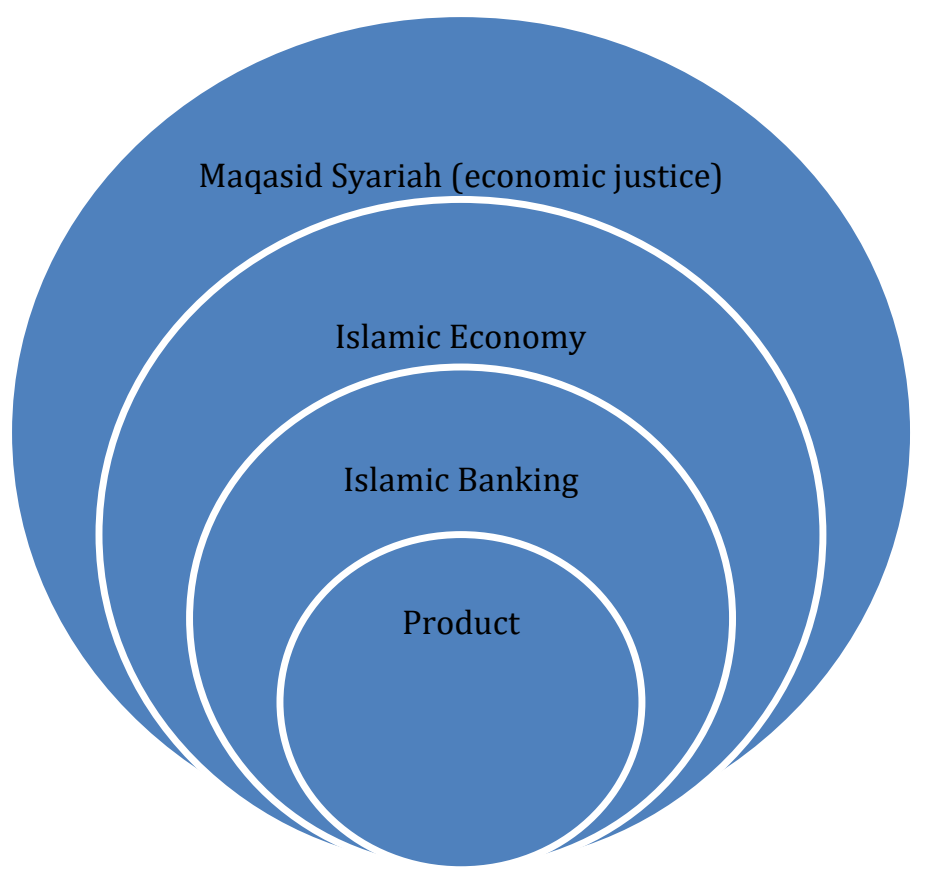

Figure 1. Diagram of Theoretical Framework

\section{Methodology}

Research activity needs a method, way or strategy to be used in research activity that aims for the explanation of several symptoms that can be seen to get the truth that we want by seeking a solution or answer from the question faced. The scientific research method varies as the variation of its subject and object, so a research planning has to determine the exact method. This research was qualitative since it focuses on the development of an explanation about a phenomenon. This research aimed for understanding the condition and trying to answering the questions "why" and "how." (Hancock, Ockleford, \& Windridge, 2009) This research was conducted as follow:

\subsection{Data}

This research used secondary data from books, journals, newspapers, annual reports and the site of Bank Muamalat, and other sources that talk about Islamic Bank, its product, and maqasid sharia.

This research examines eight financing products of Bank Muamalat as the samples which consists of KPR Muamalat iB, Automuamalat, Dana Talangan Porsi Haji, Muamalat Umroh Financing, Pembiayaan Anggota Koperasi, Capital Work Financing, LKM Syariah Financing, Pembiayaan Rekening Koran Syariah. 
The researcher collected data through library research by studying books or literature and scientific journal to obtain powerful and comprehensive theory based on maqasid sharia and the development of Islamic Bank as the agent of maqasid sharia attainment.

\subsection{Method}

The method to analyze the data in this research was descriptive-critical analysis. This analysis began with providing financing products of Bank Muamalat, and then they were analyzed one by one based on maqasid sharia.

This research analyzed the financing product of Bank Muamalat using maqasid sharia parameter. The steps for this research were as follow:

a. Collecting data sources by gathering all literature and information related to maqasid sharia and financing product of Bank Muamalat.

b. After the data was collected, the detail of Bank Muamalat financing product and the contract in that product was explained.

c. Then, the sorting process of the Bank Muamalat financing product was done based on its conformity with maqasid sharia.

The next step was to explain each financing product. Also, the indicators were differentiated into product conformity, and that is not conformed with maqasid sharia.

\section{Results and Analysis}

\subsection{Results}

Bank has been globally understood and accepted as the intermediary institution that roled to collects funds from society and then uses it to fulfill society's need for financing, which the government and the private firm could not fulfill. Based on this role, it can be concluded that the main goal of the bank (in this research is Islamic bank) is fulfilling the financing need of society. Therefore, it is important to understand the financing product of the bank and its type.

Financing is a distribution process of the fund by an Islamic bank to its customers (person or institution) to help them support their business. It aims for some goals divided into micro goals and macro ones. The micro goals of financing are to maximize profit, minimize risks, utilize the resources by combining natural, human and capital resources and distributing a surplus of funds. As for the macro goal, financing aims for developing society's economy through access to financing, providing funds to increase people's business through additional capital, increasing productivity, opening a new workplace, and distributing income (Muhammad, 2005)

To achieve their micro and macro goals, Islamic banks have evolved some types of financing products that could fulfill their customer needs. Muamalat is one of the Islamic banks in Indonesia that provides various types of financing products. Those products can be seen in the table below: 
Table 1. Financing Products of Bank Muamalat

\begin{tabular}{ccc}
\hline No & Product & Contract \\
\hline 1 & KPR Muamalat iB & Murabahah \\
2 & Dana Talangan Porsi Haji & Qard \\
3 & Automuamalat & Murabahah \\
4 & Muamalat Umroh Financing & Ijara \\
5 & Pembiayaan Anggota Koperasi & Mudaraba \\
6 & Capital Work Financing & Musharakah, Mudaraba/ Murabahah \\
7 & LKM Syariah Financing & Musharakah/ Mudaraba \\
8 & Pembiayaan Rekening Koran Syariah & Musharakah \\
\hline
\end{tabular}

Source: data processed from Bank Muamalat website

Those types of Muamalat financing products practically use some types of Islamic contract (aqad). They are murabahah, mudarabah, musharakah, istishna, ijara and qard. For the last five years, the most aqad used in Muamalat financing is musharakah and mudarabah (equity-based financing), then followed by murabahah, istishna and ijara (debt-based), as we can see in the table below:

Table 2. Composition of Muamalat Financing Contracts

\begin{tabular}{ccc}
\hline Year & Debt-Based & Equity-Based \\
\hline 2016 & $44,24 \%$ & $54,31 \%$ \\
2017 & $48,32 \%$ & $49,89 \%$ \\
2018 & $47,15 \%$ & $50,60 \%$ \\
2019 & $48,26 \%$ & $51,78 \%$ \\
2020 & $44,06 \%$ & $53,20 \%$ \\
\hline
\end{tabular}

Source: processed data from Bank Muamalat Annual Report

\subsection{Analysis}

The different principles and features of Islamic Economics than conventional is that this type of economics is based on the concepts of maqasid sharia, which includes economic wellbeing, equitable distribution of income, freedom of the individual within the context of social welfare, and universal brotherhood and justice. Islamic Banking, as the element of this system, has to promote this equity, freedom and justice, including development in products. Every development in Islamic Bank's products should not only focus on legal forms of the products but also has to be based on the greater perspective from maqasid sharia.

Attainment of maqasid sharia in the form of justice in Islamic Bank through its products, especially financing products, can be achieved by maximizing equity-based financing as suggested by Yusof and friends (Yusof, Ogie, \& Kamal, February 2010). The argument is that equity-based financing gives an equal opportunity to everyone to access the funds that they need. This type of financing promotes the idea of establishing justice in Islamic banks.

Perhaps, today's practices and products of Islamic Banking are legally accepted, but whether they fulfill the maqasid sharia regarding equitable distribution of income and promoting economic justice and growth is still in question. Most Islamic Banking products (financing) are based on debt-based financing, and only a few of them are based on equity- 
based financing (Bank Muamalat is included in it). This statement is based on the report from Sharia Banking Statistics (SPS), which can be seen as follow:

Table 3. Composition of Financing Contracts of Sharia Banking in Indonesia

\begin{tabular}{|c|c|c|}
\hline Year & Debt Based & Equity Based \\
\hline 2016 & $58,52 \%$ & $37,79 \%$ \\
\hline 2017 & $55,23 \%$ & $41,53 \%$ \\
\hline 2019 & $48,80 \%$ & $48,22 \%$ \\
\hline 2020 & $49,1 \%$ & $48,65 \%$ \\
\hline
\end{tabular}

Source: data processed from Sharia Banking Statistics (SPS) 2020

To know how much Muamalat financing products are oriented to maqasid sharia, we can analyze those products as follow:

Basically, Islamic Banks operate by two modes of financing. They are core modes that are based on the principle of profit and loss sharing (PLS) and marginal modes that are based on mark-up and other non-PLS principles. The first modes include mudaraba and musharakah. The second modes include murabahah, ijara, istishna, salam, and qard. As for Muamalat, it bases its eleven types of financing products on five kinds of aqad and the most aqad in Muamalat financing products is musharakah.

Musharakah was originally a contract between two parties or more through the capital joint. The parties contribute in the capital though not both of them have to contribute in work. This cooperation will give the parties a proportionate gain they agreed beforehand, while they will bear any loss that occurred based on their contribution in the capital. Also, there is no collateral asked for this contract except the trust.

The modern practice of musharakah in Islamic Bank uses this contract as the product of capital work financing or investment where the bank provides financing for the entity who has business license and collateral compatible with the financing proposed. Though this type of financing is based on a profit and loss sharing system, it is beyond the maqasid shariah. Stated as it is because, in this financing, the customer has to provide collateral for financing he proposes. The obligation of the customer to provide collateral will secure the bank from the loss if any loss occurs in customer business. This security will break the profit and loss sharing system since the bank secures itself from any loss by holding collateral from the customer. In another sense, the obligation to provide collateral will make the difference in funds that the customer could access. The customer could only access the funds based on the collateral he could present. In the sense of justice, this practice of musharakah leads to injustice where there is no equal opportunity to access the fund because of their difference in the ability to provide requested collateral.

Muamalat uses musharakah contract in some of its financing products, namely KPR Muamalat iB, Capital Work Financing, Pembiayaan Hunian Syariah and iB Unit Mikro Muamalat. These financing products of Muamalat are also based on collateral provides. Though these products are legally accepted in Islam, for the reason of justice, these products have to be evaluated further. By practicing musharakah contract by collateral in these 
products, Muamalat could be regarded as another Islamic Bank that cover the poor access to funds that it provides.

The next contract is mudaraba. It was originally a joint contract between a capital owner and a worker based on the PLS system. The gain would be divided to the capital owner and worker based on agreed proportion, while any loss happened, the capital owner would bear the financial loss and the worker bear loss of time, energy and opportunity to get gain from the business.

This original concept is totally different from Islamic Bank practice today. Mudaraba contract in Islamic Bank nowadays is similar to musharakah contract where the bank provides financing for the customer who already has business at least for a year by means already has his own capital and need to propose another capital requirement through the financing of Islamic Bank. In this condition, the bank is not completely the capital owner, and the worker is not completely an agent. The relationship between bank and customer is not the sahibul mal and mudarib, but as a joint partner as in the musharakah contract instead.

Mudaraba's contract in Muamalat is less interesting. Even so, this type of contract is used for both LKM Shariah Financing and Pembiayaan Anggota Koperasi. Though the practice of mudaraba is different from its original form, it does not mean that it is not legally accepted. Since the change of the time and need of the customer and since the regulation, this practice of mudaraba is acceptable by the scholars. Similarly, in musharakah contract, mudaraba contract also needs the liability of the customer to provide collateral in it. This factor automatically makes only customers who can make it get access to this financing, but the one who has no ability will not get access to it. This aspect makes the practice of mudaraba in Muamalat financing products need to be evaluated far more to obtain maqasid sharia.

Murabaha was used in specific conditions with the objective to protect some innocent consumers who did not know well about trading and the price of commodities they wanted to buy. In Islamic Bank practice, a bank is permitted to point out its customer to buy a commodity he wants as an agent of the bank. Basically, this practice is incompatible with its original one, but this could be permitted by the assumption that customers nowadays perhaps know better than the bank itself about commodities they want while they do not have enough money to acquire the commodities, so they need the bank's help.

Another controversy in murabaha contract is the difference between cash and credit price. Some discern this difference as riba, while some others claim that the difference is the justice for the bank. The equal price for cash and credit will make banks suffer some losses. First, the change in the value of money over time. Second, loss of opportunity to immediately invest its fund in another project. Islam promotes justice not only for the customers but also for business enterprises themselves. Since the difference between cash and credit prices is to promote justice for banks and by an agreement between bank and customer, this difference could be permitted.

Due to Islam promotes justice for both banks and customers, justice for the customer could be attained by supplying equal opportunity to access bank funds for every customer 
regardless of their economic condition, where the rich and the poor have equal access to Islamic Bank's fund. This is how Islamic Bank's products should be. But the fact, an advance system in murabaha contract will cover the opportunity to access the fund for those who do not have enough money to pay in advance. Another aspect that makes murabaha practice in Islamic Banking creates injustice is fixed installment determined that has to be fulfilled by the customer monthly. The obligation to pay fixed installments is another factor that will shut the opportunity for the poor to access Islamic Bank's fund because they have no fixed income or revenue to fulfill it.

Muamalat uses murabaha contract in some financing products, such as in Automuamalat, KPR Muamalat iB, Investment Financing, Capital Work Financing and Pembiayaan Anggota Koperasi. For another Islamic Bank's practice, murabaha contract is applied in these financing products of Muamalat and also based on credit sale by advance and fixed installment. Though these products are legally accepted in Islam, for the reason of justice, these products have to be evaluated further. By practicing murabaha contract by advance and fixed installment in these products, Muamalat could be regarded as another Islamic Bank that covers the poor access to funding that it provides.

The least two contracts used in Muamalat financing products are ijara and qard. Ijara is used for Muamalat Umroh Financing, while qard is used for Dana Talangan Porsi Haji. Ijara is set up for any commodity or asset for a certain price. Based on this setup, the contract will ensure compliance with sharia if only the two conditions are satiable for both asset and price. While in Muamalat Umroh Financing, only the price exists, but there is no commodity or asset to be leased for.

Principally, the legal aspect of this contract does not directly talk about its justice dimension. But literally, justice is placing something in its right place. Based on the original scheme of ijara, Muamalat Umroh Financing is not placing ijara in its right place, so it could be considered as injustice. The existence of injustice is regarded as the failure in obtaining maqasid sharia.

Another reason for the failure of Muamalat Umroh Financing product in using ijara contract to obtain is the existence of debt created by it. Justice in the form of equal opportunity to access capital gives every person a chance to get financing in the form of capital, instead of creating debt.

The last one is qard. Although qard is not categorized into equity-based financing or debtbased financing, the product of Dana Talangan Porsi Haji based on this contract could be considered as not promoting maqasid sharia. The reason for it is because this product provides the loan for Muslims to pilgrimage to Mecca. Muslims could pilgrimage to Mecca not for its financial ability anymore but for the easy access to debt.

Principally, pilgrimage becomes the obligation of Muslims when they are capable mentally and financially. When Muslims go for pilgrimage by a loan from the bank, they are not capable financially. This debt then will create an obligation for them to pay after the pilgrimage. Like ijara, the qard contract in this product could also be considered as injustice by mean doing the obligation when still has no capability to do it. Also, like Muamalat Umroh 
Financing, Dana Talangan Porsi Haji gives every person the chance to access financing in the form of debt, not in the form of capital.

Based on the categorized before, we can conclude that most Muamalat financing products do not promote the establishment of justice, which is part of maqasid sharia. Though, those products give benefit to those engaged in them, which partly obtain maqasid sharia.

Attainment of maqasid sharia through only one framework is barely enough to show that Muamalat has become the best Islamic Bank.ing in Indonesia that conquers the spiritual market. To attain that target comprehensively, Muamalat has to fulfill the maqasid sharia through its products in the framework of justice establishment by giving equal opportunities to everyone to access capital sources regardless of their status.

\section{Conclusion and Recommendation}

\subsection{Conclusion}

Based on the theories, data presented, and the result of data analysis that refer to the problem and objective of this research, the financing product of Muamalat shows that they could be considered as the attainment of maqasid sharia because those products are dominantly provided in the equity-based contract that will not separate the access to capital between the rich and the poor. However, the conditions determined for an equity-based contract in Muamalat's financing products, and considered as not promoting maqasid sharia:

The first is the musharakah contract. Though this type of financing is based on a profit and loss sharing system, it is beyond the maqasid shariah. Stated as it is because, in this financing, the customer has to provide collateral for financing he proposes. The obligation of the customer to provide collateral will secure the bank from any occurring losses. This security will break the profit and loss sharing system since the bank secures itself from any loss by holding collateral from the customer. In another sense, the obligation to provide collateral will make the difference in funds that could be accessed by the customer. The customer could only access the funds based on the collateral he could present. In the sense of justice, this practice of musharakah leads to injustice where there is no equal opportunity to access the fund because of their difference in the ability to provide requested collateral.

Second, similar to musharakah contract, mudaraba contract also need the liability of the customer to provide collaterals. This factor automatically makes only customers who can make it get access to this financing, and others can't. This aspect makes the practice of mudaraba in Muamalat financing products need to be evaluated further to obtain maqasid sharia.

Third, although the murabaha contract is legally accepted in Islam, for the reason of justice, this contract has to be evaluated further. By practicing murabaha contract by advance and fixed installment in these products, Muamalat could be regarded as another Islamic Bank that covers the poor access to funding that it provides. 
Forth, based on the original scheme of ijara, Muamalat Umroh Financing is not placing ijara in its right place, so it could be considered as injustice. The existence of injustice is regarded as the failure in obtaining maqasid sharia. Another reason for the failure of Muamalat Umroh Financing product using ijara contract to obtain is the existence of debt. Justice in the form of equal opportunity to access capital gives every person a chance to get financing in the form of capital, instead of creating debt.

Fifth, although qard is not categorized into equity-based financing or debt-based financing, the product of Dana Talangan Porsi Haji based on this contract could be considered contrary to maqasid sharia. The reason is that this product provides a loan for Muslims to pilgrimage to Mecca. Asa result, Muslims could pilgrimage to Mecca not for their financial ability anymore but due to the easy access to debt.

This research was limited to secondary data on Bank Muamalat Financing Products so that the conclusion was solely based on the percentage of contract, type and characteristics of financing products. Suggestion for next research is to use primary data such as the interview with Bank Muamalat officer and questionnaire for Bank Muamalat customer to get better examination and valuation on Bank Muamalat attainment of maqasid sharia.

\subsection{Recommendation}

This research suggests some recommendations as follow:

a. Bank Muamalat in particular and Islamic Bank in Indonesia, in general, need to reevaluate their offered products. The evaluation is not only in the aspect of sharia compliance but also in relation to a wider aspect, such as the benefit of all parties (maslahah).

b. Regulators are deemed necessary to create an appropriate competitive environment for Islamic banks to achieve their social goals and to promote maqasid sharia.

\section{References}

Abozaid, A., \& Dusuki, A. W. (2007). The Challenges of Realizing Maqasid Shariah in Islamic Banking and Finance. International Conference on Islamic Banking and Finance (pp. -). Kuala Lumpur: IIUM.

Abu Zahrah, Muhammad. (1958). Ushulu al-Fiqh. Damaskus: Dar al-Fikr al-'Arabi.

Ahmed, H. (2011). Maqasid Shari'ah and Islamic Financial Products: a Framework for Assessment. ISRA International Journal of Islamic Finance , 149.

Al-Buti, M. Said Ramadhan. (2005). Dhawabit al-Mashlahah al-Shari'ah al-Islamiyah. Damaskus: Dar al-Fikr.

al Mubarak, T., \& Osmani, N. M. (2010, - -). Applications of Maqasid al Shariah and Maslahah in Islamic Banking Practices: an Analysis. Retrieved May 15, 2021, from IIUM: http://irep.iium.edu.my

Al-Zuhayli, Wahbah. (1986). Ushulu al-Fiqhi al-Islami. Damaskus: Dar al-Fikr, Vol. 2.

Antonio, M. S. (2001). Bank Syariah: Dari Teori ke Pr aktik. Jakarta: Gema Insani Press.

Antonio, M., D., S., \& Taufiq, M. (2012). An Analysis of Islamic Banking Performance: Maqasid Index Implementation in Indonesia and Jordania. Journal of Islamic Finance, Vol.1,No.1 , 012-029. 
As-Shatibi, Ibrahim Ibn Musa Ibn Muhammad. (2006). Al-Muwafaqat. Kairo: Dar Ibn 'Affan, Volume 2, Edition 2.

Auda, J. (2007). Fiqh al-Maqasid: Inathah al-Ahkam al-Shar'iyyah bi Maqasidiha. USA: International Institute of Islamic Thought.

Auda, J. (2008). Maqasid al-Shari'ah: a Beginner's Guide. Occasional Paper Series 14 , - .

Bakri, A. J. (1996). Konsep Maqasid al-Syariah Menurut al-Syatibi. Jakarta: RajaGrafindo Persada.

Bedoui, H., \& Mansour, W. (2013). Islamic Bank Performance and Maqasid Shariah. 9th AsiaPacific Economic Association Conference (pp. -). Osaka: -.

Dusuki, A. W., \& Bouheraoua, S. (2011). The Framework of Maqasid Sharia (Objectives of the Sharia) and Its Implications for Islamic Finance. ISRA Research Paper, No.22 , - .

Hancock, Beverley, Elizabeth Ockleford and Kate Windridge. (2009). An Introduction to Qualitative Research. Nottingham: NIHR RDS.

Hosen, M. N., \& Nahrawi, A. A. (2012). Comparative Analysis of Islamic Banking Products between Malaysia and Indonesia. International Journal of Academic Research in Economics and Management Sciences, Vol.1, No.2 , -

Indonesia, R. M. (2012). Pembangunan Ekonomi Umat: Tafsir al-Qur'an Tematik. Jakarta: Direktorat Urusan Agama Islam dan Pembinaan Syariah.

Jalil, A. (2006). The Significances of Maslahah Concept and Doctrine of Maqasid (Objectives) al-Shariah in Project Evaluation. The Journal of Muamalat and Islamic Finance Research (JMIFR), Vol.3, No.1 , 171-202.

Karim, A. (2013). Bank Islam: Analisis Fikih dan Keuangan. Jakarta: RajaGrafindo Persada.

Meryana, E. (2013, September 18). Bank Muamalat Kembali Jadi Bank Syariah Terbaik di Indonesia. Retrieved May 14, 2021, from swa: http://www.swa.co.id

Mohammad, M. O., \& Shahwan, S. (2013). The Objectives of Islamic Economic and Islamic Banking in Light of Maqasid Shari'ah: a Critical Review. Middle-East Journal of Scientific Research , 75-84.

Mohammad, M. O., Razak, D. A., \& Taib, F. M. (n.y., - -). The Performance Measures of Islamic Banking Based on the Maqasid Framework. Retrieved April 05, 2020, from IREP IIUM: http://www.irep.iium.edu

Muamalat, B. (2016, - -). Annual Report. Retrieved May 14, 2021, from Bank Muamalat: http://www.muamalatbank.com

Muamalat, B. (2018, - -). Annual Report. Retrieved May 14, 2021, from Bank Muamalat: http://www.muamalatbank.com

Muamalat, B. (2020, - -). Annual Report. Retrieved May 14, 2021, from Bank Muamalat: http://www.muamalatbank.com

Muhammad. (2005). Manajemen Pembiayaan Bank Syariah. Yogyakarta: UPP AMP YKPN.

OJK. (2020, Desember -). Statistik Perbankan Syariah. Retrieved May 15, 2021, from 0JK: http://www.ojk.go.id

Rawls, J. (2005). A Theory of Justice. Cambridge: Harvard University Press.

Rosly, S. A. (2010). Shariah Parameters Reconsidered. International Journal of Islamic and Middle Eastern Finance and Management, Vol.3, No.2 , -.

Shaharuddin, A. (2010). Maslahah-Mafsadah Approach in Assessing the Shariah Compliance of Islamic Banking Products. International Journal of Business and Social Sciences, Vol.1, No.1, -

Suharso, Y. (2014, February 24). Bank Muamalat Indonesia, Bank Syariah Terbaik Enam Kali. Retrieved May 14, 2021, from mysharing: http://www.mysharing.com

Yusof, E. F., Ogie, J. K., \& Kamal, A. A. (February 2010). Islamic Finance: Debt versus Equity Financing in the Light of Maqasid Shariah. MPRA Paper, No.20722 , - . 